\title{
Effect of ethanolic seed extract of Caesalpinia bonducella on hormones in mifepristone induced PCOS rats
}

\author{
Balasubramanian Meera Murugesan ${ }^{1}$, Palayyan Muralidharan ${ }^{2}$, Rajeswary Hari ${ }^{*}$ \\ ${ }^{1}$ Department of Biotechnology, Dr. MGR Educational and Research Institute, Chennai, India. \\ ${ }^{2}$ Department of Pharmacology, C. L. Baid Metha College of Pharmacy, Chennai, India.
}

\begin{tabular}{l}
\hline ARTICLE INFO \\
\hline Received on: 23/05/2019 \\
Accepted on: 20/12/2019 \\
Available online: 05/02/2020 \\
\\
\hline Key words: \\
Caesalpinia bonducella, \\
ESECB, PCOS, ifepristone.
\end{tabular}

\section{INTRODUCTION}

Polycystic ovarian syndrome (PCOS) is known to be one of the most common endocrine disorders, affecting approximately $7 \%$ of women during their reproductive period (Aubuchon and Legro, 2011). The major cause of the syndrome is infertility which was characterized by chronic anovulation hyperandrogenemia, altered luteinizing hormone (LH):follicle stimulating hormone $(\mathrm{FSH})$ ratio and insulin resistance (Shannon, 2012). The insulin resistance has an important influence in the PCOS pathogenesis through the development of hyperinsulinemia, which leads to hyperandrogonism and further complications (Poretsky et al., 1999). Moreover, in PCOS women, as insulin resistance is the major cause of metabolic syndrome and cardiovascular diseases, the treatment strategies mainly involves the use of insulin sensitizing drugs and life style modifications (Spritzer, 2014). These drugs helps to ameliorate

\section{"Corresponding Author}

Rajeswary Hari, Department of Biotechnology, Dr. MGR Educational and Research Institute, Chennai, India.E-mail: rajihar@gmail.com insulin resistance, decrease serum testosterone, and improve ovulation (Lord et al., 2003), but they may have numerous side effects (Desai et al., 2012), and hence an alternate therapy in the form of phyto medicine can be implemented.

Today, worldwide, there is a revival shift toward folklore traditional "green therapy "in the form of medicinal plants from the expensive synthetic drugs which has numerous side effects. The medicinal plant Caesalpinia bonduella belongs to the family Caesalpiniaceae, which is widely distributed all over the world, and in India, especially found in the tropical regions (White et al., 2005), considered as an important remedy for the treatment of several diseases. All parts of the plant have been reported to have many therapeutic properties and it also has alkaloids, flavanoids, glycosides, saponins, tannins, and triterpenoid (Gaur et al., 2008; Gupta et al., 2005), and the seeds of the plant are reported for its antioxidant, anti inflammatory, antipyretic, and analgesic activities (Shukla et al., 2010). Although the seed contains many medicinal properties, it has not been evaluated scientifically in the treatment of PCOS. Hence, the current study was undertaken to evaluate the effect of ESECB on altered hormonal levels in PCOS-induced female rats. 


\section{MATERIALS AND METHODS}

The substance Mifepristone was purchased from Merck Millipore and the hormone assay kits used were obtained from TOSOH LILAC India Pvt Ltd. The other chemicals used are of analytical grade.

\section{Method of preparation of ESECB}

Caesalpinia bonducella seeds were purchased from Chennai local market and were authenticated by Professor Dr. Mythreyi, Pharmacognosy Department, K. K. College of Pharmacy, Chennai, India. Then, the seeds were made into powder after drying in shade, and using 95\% ethanol it was extracted at room temperature by cold maceration process in 3 days. Then, the extract was filtrated and using rota flash evaporator, it was made evaporated and sample yield was calculated which was about $1.25 \% \mathrm{w} / \mathrm{w}$, and it was used for analysis.

\section{Animals}

Wistar strain Adult albino female rats from C.L Baid Mehta College of Pharmacy Chennai were taken for pharmacological studies. Animal maintenance were carried out with natural $12 \pm 1$ hour day-night cycle, in the propylene cages, and a balanced rodent diet in the form of pellets and tap water was provided throughout the experimental period. The rats were sheltered for 1 week in the laboratory for acclimatization before the experimental period. The experimental protocol was approved by the Animal Ethics Committee constituted for the purpose as per CPCSEA (12/321/PO/Re/S/01/CPCSEA dated 12/10/18).

\section{Acute toxicity studies}

The acute toxicity studies for $C$. bonducella ethanolic extract were conducted previously by Kshirsagar et al. (2012) as per the Organisation for Economic Co-operation and Development (OECD) guidelines 420, up to the test dose of $2,000 \mathrm{mg} / \mathrm{kg}$, and it was reported that there was no mortality. One tenth of the LD50 dose that is $200 \mathrm{mg} / \mathrm{kg}$ b.w. as low dose and a higher dose of 400 $\mathrm{mg} / \mathrm{kg} \mathrm{b.w}$. was selected additionally in the present study.

\section{Induction of PCOS by Mifepristone in female rats}

Administration of antiprogesterone Mifepristone RU486 (4 mg / $0.2 \mathrm{ml}$ oil) to 4 days estrous cyclic rats over eight consecutive days starting on the day of estrus (day 1) as per Sanchez-Criado et al. (1993) method. To observe and monitor the development of PCOS condition in the rats, by irregular estrous cycle daily, vaginal smear test was conducted followed by the Mifepristone RU486 injection. Once an anovulatory cystic ovary condition similar to those exhibited in polycystic ovary disease is confirmed through persistent vaginal cornification stage, animal grouping was done for further treatment.

\section{Animal grouping and treatment pattern}

Thirty adult female Wistar rats were taken for the analysis which was segregated into five groups constituting of six animals each.

Group I-Served as a normal control was administered only with the vehicle [2\% carboxy methyl cellulose (CMC) Suspension)]

Group II-Served as a negative control received Mifepristone RU486 alone
Group III-PCOD-induced rats treated with ESECB $200 \mathrm{mg} / \mathrm{kg}$ b.w. for 28 days

Group IV-PCOD-induced rats treated with ESECB $400 \mathrm{mg} / \mathrm{kg}$ b.w. for 28 days

Group V-Served as a standard was treated with Metformin 20mg/kg b.w. for 28 days

\section{Blood sample}

After the dosing procedure of ESECB to all the animals, they were sacrificed under mild anesthesia. The blood samples were collected in sterile eppendorff tubes by retro-orbital puncture, and serum was separated by centrifugation at 3,000 rpm for 10 minutes, and it was used for the hormone assay.

\section{Estimation of hormonal assay}

Assay of hormones, such as LH, FSH, prolactin (PRL), testosterone (T), estrone, estradiol, progesterone, and insulin were determined by Enzyme-Linked Immuno Sorbent Assay (ELISA) method using commercial diagnostic kits (TOSOH LILAC India Pvt Ltd).

\section{Statistical analysis}

The values reported are mean \pm SE. The statistical analysis was carried out using analysis of variance (ANOVA) followed by Dunnet's " $t$ " test. The $p$ values $<0.05$ were considered as significant.

\section{RESULTS}

\section{Effect of ESECB on LH, FSH, insulin, and PRL levels}

The effect of the ESECB extract on the hormones, such as LH, FSH, insulin, and PRL was shown in Figure 1. It is observed that there is a significant increase in the level of LH and decreased level of FSH in the PCOS-induced group II rats comparable $(p<0.01)$ to the control rats, which indicates the presence of irregular ovulatory process. Group III and Group IV Mifepristone-induced PCOS rats which received the ESECB drug treatment showed a decrease in the level of LH and an increase in the level of FSH indicating its restoration of ovulation.

It is also observed that there is a significant increase in the level of insulin and PRL in the PCOS-induced Group II rats comparable to control rats indicating the presence of hyperinsulinemia, a principal feature of PCOS. These levels were reverted back significantly in the PCOS-induced and ESECB drugtreated group III and Group IV animals. The animals that received $400 \mathrm{mg} / \mathrm{kg}$ b.w of ESECB extract showed a considerable decrease of insulin level which and the decrease was quite significant than the positive control. Metformin used in the present study indicating the potential of the drug extract in improving the insulin sensitivity.

\section{Effect of ESECB on testosterone, estrone, estradiol, and} progesterone levels

The effect of ESECB extract on the hormones, such as testosterone, estrone, estradiol, and progesterone was shown in Figures 2 and 3. From the figures, it is observed that there is a significant increase $(p<0.01)$ in the level of testosterone, estrone, and estradiol in the group II PCOS-induced rats than the normal control group. It was also observed that the values reverted back significantly in the ESECB drug-treated group III and Group IV rats. 


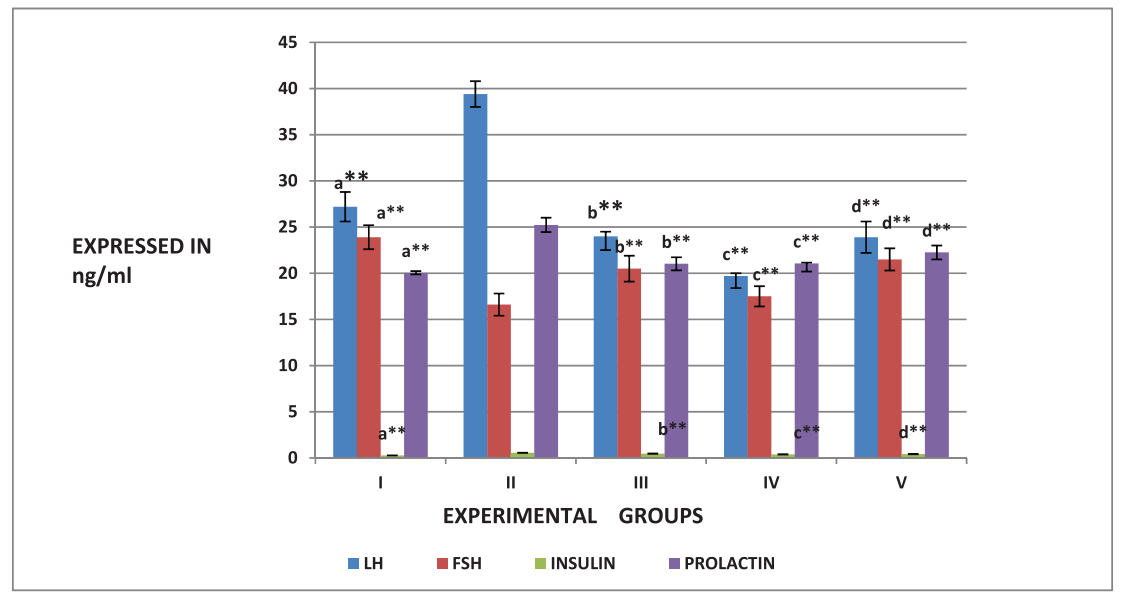

Figure 1. Effect of ESECB on LH, FSH, insulin, and PRL levels in female rats. Values are mean \pm SEM of six animals in each group. Statistical significant test for comparison was done by ANOVA followed by Dunnet's " $t$ ” test. Comparison between a - Group I versus Group II, b-Group II versus Group III, c - Group II versus Group IV, and d-Group II versus Group V. $p$ values — ${ }^{*} p<0.05,{ }^{* *} p$ $<0.01,{ }^{* * *} p<0.001$, NS-Not Significant.

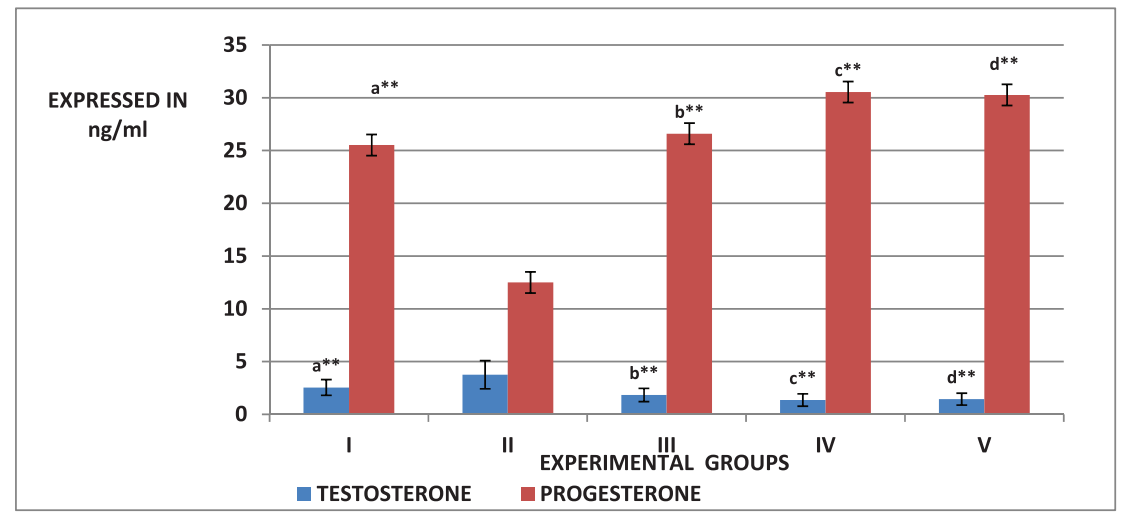

Figure 2. Effect of ESECB on testosterone and progesterone levels in female rats. Values are mean \pm SEM of six animals in each group. Statistical significant test for comparison was done by ANOVA followed by Dunnet's " $t$ " test. Comparison between a - Group I versus Group II, b - Group II versus Group III, c - Group II versus Group IV, and d-Group II versus Group V. $p$ values — $* p<0.05, * * p$ $<0.01,{ }^{* *} p<0.001$, NS-Not Significant.

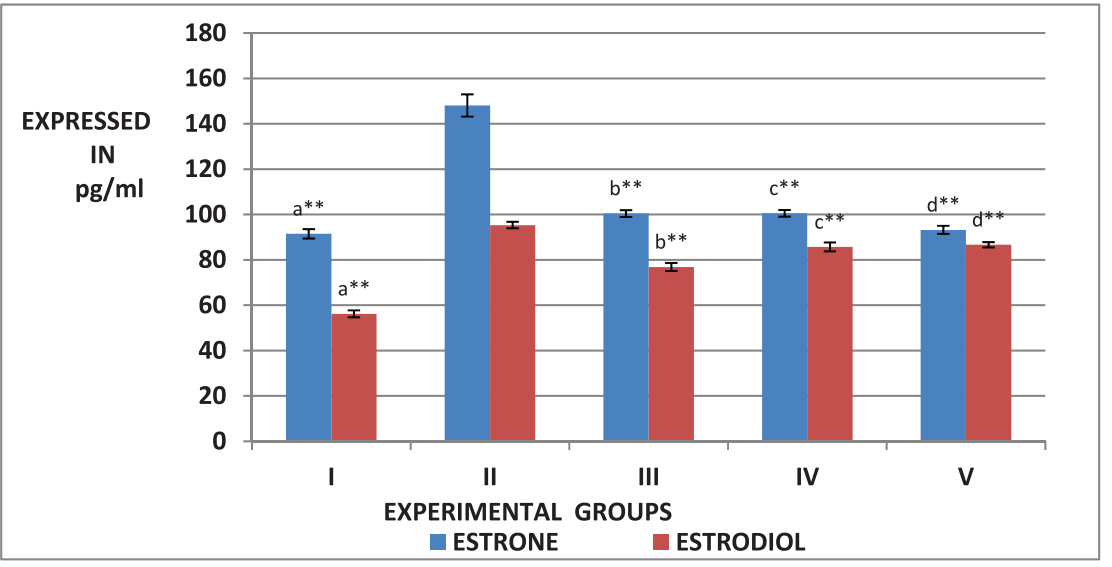

Figure 3. Effect of ESECB on estrone and estradiol levels in female rats. Values are mean \pm SEM of six animals in each group. Statistical significant test for comparison was done by ANOVA followed by Dunnet's " $t$ " test. Comparison between a - Group I versus Group II, b-Group II versus Group III, c - Group II versus Group IV, and d-Group II versus Group V. $p$ values—* $p<0.05,{ }^{* *} p<0.01$, $* * * p<0.001$, NS-Not Significant. 
From the figure, it is observed that there is a significant increase $(p<0.01)$ in the level of testosterone, estrone, and estradiol in the group II PCOS-induced rats than the normal control group. The ESECB drug treatment reverted back these reproductive hormone levels significantly in Group III and Group IV rats. In the present study, the decreased progesterone level was observed due to mifepristone treatment which was increased by the ESECB drug treatment indicating the potential of drug extract in reverting the action of antiprogesterone mifepristone.

\section{DISCUSSION}

PCOS is an endocrine disorder which has multiglandular pathophysiology involving hypothalamic, pituitary, and ovarian axis, leading to the disturbances in the cyclic reproductive mechanisms with metabolic complications, such as hyperinsulinemia, insulin resistance, dyslipidemia, and obesity (Teede et al., 2006). RU486 is an antagonistic synthetic steroid which possesses high affinity for the progesterone and glucocorticoid receptors inhibit the progesterone activity and cause disturbances in the endocrine functions as seen in PCOS (Baulieu, 1991). Treating the adult cycling female rats with RU486 for 4-9 days produces PCOS, anovulation, acclivity with elevated levels of serum LH, T, and estrogen levels (Yung et al., 2014). In the present investigation, an attempt is made to study the effect of ESECB on hormonal parameters in RU486-(mifepristone) induced PCOS rats.

Generally, it is accepted that the anovulation causes disturbances in the feedback signaling from ovarian sex hormones to the hypothalamus and pituitary which in turn, affect the release of the gonadotropin-releasing hormone $(\mathrm{GnRH})$, thereby disturbs the normal release of LH and FSH. In the present investigation, there is an increase in the $\mathrm{LH} / \mathrm{FSH}$ ratio and $\mathrm{LH} / \mathrm{FSH}$ ratio greater than two is considered as "gold standard for evaluating the gonadotropin status in PCOS" (Teede, 2010). It is also reported by Feng et al. (2013) that increased levels of LH may be due to the impaired feedback of estrogen which in turn stimulates the abnormal proliferation of theca cells, thereby inducing the PCOS condition. The ESECB extract significantly corrected the LH/FSH ratio by reducing $\mathrm{LH}$ levels considerably, and thereby protecting the ovaries from the excess proliferation of the theca cells and helps in the prevention of PCOS condition.

In the present study, a notable increase in the PRL level is observed in the PCOS rats and ESECB helped in lowering the PRL levels. This observed hyperprolactinemia may be either due to elevated levels of estrogen and testosterone or due to the modifications in the pulsatile release of $\mathrm{GnRH}$ which causes alteration in the normal LH/FSH ratio. In the ovary, PRL blocks folliculogenesis and inhibits granulosa cell aromatase activity, leading to hypoestrogonism and anovulation (Kulshreshtha et al., 2017). The reduction in body weight and reproductive organs is carried out by correcting the impaired metabolic functions by numerous phytochemicals, such as bonducin, proteins, saponin, starch, sucrose, two phytosterols, namely sitosterol and hepatsane, fatty acids, such as palmitic acid, stearic acid, lognoceric, oleic, linolenic acid which is present in C. bonduella seeds (Gurunath et al., 2010).

Among the several androgens, testosterone is considered as the most important one which is derived partly from adrenal glands and partly from ovaries in normal women. However, according to Marshall (2001), the whole source testosterone is from ovaries in the case of women with PCOS.

Moreover, as stated by Cibula et al. (2002), low levels sex hormone binding globulin (SHBG) is also directly connected with the increased concentration of unbound androstenedione and testosterone leading to hyperandrogonism. Hyperandrogonism leads to hyperinsulinemia by altering the glucose metabolism. In the presence of increased androgens, the peripheral and hepatic insulin action is inhibited which in turn leads to insulin resistance as stated by Gambineri et al. (2002) that a complex reciprocal interaction exists between the hyperandrogenemia and insulin sensitivity. According to Wallace et al. (2013), the decreased concentrations of SHBG is due to the increase in the insulin levels which is another important hall mark in the pathophysiology of PCOS since insulin has an inhibitory activity on SHBG synthesis in the hepatic cells.

In our present investigation, we observed elevated levels of testosterone and insulin hormones in the mifebristone-induced PCOS rats which might have caused significant increase in the insulin resistance when compared to the control normal rats. This may be attributed to the fact that either there may be defect in the insulin, binding to the receptors or may be due to the decrease in the number of insulin receptor, which is due to the decrease in the insulin sensitivity for glucose transport stimulation in PCOS women as stated by Ciaraldi et al. (1992). In the pathogenesis of PCOS, insulin plays direct and indirect roles for hyperandragonism. In spite of other tissues being resistance to insulin, ovarian tissues becomes hyperactive to insulin and increased steroidogenesis, especially androgen synthesis is being observed. Moreover, insulin along with LH stimulates the theca cells to produce androgens leading to chronic hyper andragonism and elevating the complications of PCOS (Baillargeon and Nestler, 2006; Diamanti-Kandarakis et al., 2008). Oral administration of ESECB extract considerably reduced the levels of insulin and testosterone indicating the suppressive effect of insulin resistance. Previous studies by Nadaf et al. (2017) and Ghosh et al. (2012) have showed the hydro alcoholic extract has the potential of reducing blood glucose level. According to Shukla et al. (2011), the phytoconstituents present in the C. bonducella considerably reduces the insulin resistance. Since the PCOS inducer used in the present study is an antiprogestin, the serum progesterone level was found to be low in the PCOS rats which are an indicator of anovulation (Srivastava et al., 2006). The drug treatment considerably increased the progesterone levels so that it may be expected to stimulate the ovulatory process and reduce the complications of PCOS.

\section{CONCLUSION}

It is concluded that the endocrine-based metabolic factors, such as hyperinsulinemia, insulin resistance, and hyperandrogonism may lead to anovulation which is the main cause for the pathophysiology in PCOS cases. Owing to the presence of several phytochemicals, ESECB could ameliorate the multiple complications, such as hyperinsulinemia, insulin resistance, and hyperandrogonism, thereby promote ovulation can be used as an alternative therapeutic drug for the treatment of PCOS.

\section{CONFLICT OF INTEREST}

The authors declare that they have no conflicts of interest. 


\section{FINANCIAL SUPPORT}

None.

\section{REFERENCES}

Aubuchon M, Legro RS. Polycystic ovary syndrome: current infertility management. Clin Obstet Gynecol, 2011; 54(4):675-84.

Baillargeon J-P, Nestler JE. Polycystic ovary syndrome: a syndrome of ovarian hypersensitivity to insulin? J Clin Endocrinol Metab, 2006; 91:22-4.

Baulieu EE. The antisteroid RU486: its cellular and molecular mode of action. Trends Endocrinol Metab, 1991; 2:233-9.

Ciaraldi T, El-Roeiy A, Madar, Z. Cellular mechanisms of insulin resistance in polycystic ovarian syndrome. J. Clin. Endocrinol. Metab, 1992; 75:577-83.

Cibula D, Skrha J, Hill L, Fanta M, Haakova A, Zivny J. Prediction of insulin sensitivity in non obese women with polycystic ovary syndrome. J Clin Endocrinol Metab, 2002; 87:5821-5.

Desai BN, Maharjan RH, Nampoothiri LP. Aloe barbadensis Mill. Formulation restores lipid profile to normal in a letrozole-induced polycystic ovarian syndrome rat model. Pharmacognosy Res, 2012; 4(2):109-15.

Diamanti-Kandarakis E, Argyrakopoulou G, Economou F, Kandaraki E, Koutsilieris M. Defects in insulin signaling pathways in ovarian steroidgenesis and other tissues in polycystic ovary syndrome (PCOS). J Steroid Biochem Mol Biol, 2008; 109:242-6.

Feng, Y, Li X, Shao R. Genetic modeling of ovarian phenotypes in mice for the study of human polycystic ovary syndrome. Am J Transl Res, 2013; 5(1):15-20.

Gambineri A, Pelusi C, Vicennati V, Piggott U, Pasquali R. Obesity and the polycystic ovary syndrome". Int J Obesity Relat Metab Discord, 2002; 26(7):883-96.

Gaur RL, Sahoo MK, Dixit S, Fatma N, Rastogi S, Kulshreshtha DK, Chatterjee RK, Murthy PK. Antifilarial activity of Caesalpinia bonducella against experimental filarial infections. Ind J Med Res, 2008; 128:65-70.

Ghosh D, Chatterjee K, De D, Jana K, Ali K, Bera T. Antihyperglycemic and anti oxidative effects of the hydro-methanolic extract of the seeds of Caesalpinia bonducella on streptozotocin-induced diabetes in male albino rats. Pharmacognosy Res, 2012; 4:57.

Gupta M, Mazumder UK, Kumar RS, Sivakumar T, Gomathi P, Rajeshwar Y. Antioxidant defense system induced by a methanol extract of Caesalpinia bonducella. in rat liver. J Pharmacol Sci, 2005; 43(5):411-9.

Gurunath HM, Sidramayya MS, Patil KS, Wadkar GH. Effect of Caesalpinia bonducella seed extracts on human neutrophil. J Pharmacy Res, 2010; 3(3):467-9.

Kshirsagar SN, Sakarkar DM, Deshpande SS. Evaluation of acute and sub-acute toxicity of ethanolic extract of seed kernels of caesalpinia crista (linn.) in albino rats. Int J Pharm Sci Res, 2012; 3:1164-8.

Kulshreshtha B, Pahuja I, Kothari D, Chawla I, Sharma N, Gupta S, Mittal A. Menstrual cycle abnormalities in patients with pro lactinoma and drug-induced hyperpro lactinemia. Indian J Endocrinol Metab, 2017; 21:545-50.

Lord J, Flight I, Norman R. Metformin in polycystic ovary syndrome: systematic review and meta-analysis. BMJ, 2003; 327:951-3.

Marshall K. Polycystic ovary syndrome: clinical considerations. Altern Med Rev, 2001; 6(3):272-92.
Nadaf R. A study of hypoglycemic effect of Caesalpinia bonducella extract on alloxan induced diabetic albino rats. Int J Basic Clin Pharmacol, 2017; 6:2153.

Poretsky L, Cataldo N, Rosenwaks Z, Guidice L. The insulin-4 related ovarian regulatory system in health and disease. Endocr. Rev, 1999; 20:532-82.

Sanchez-Criado JE, Sanchez A, Ruiz A, Gaytan F. Endocrine and morphological features of cystic ovarian condition in antiprogesterone RU486-treated rats. Acta Endocrinol (Copenh), 1993; 129:237-45.

Shannon M, Wang Y. Polycystic ovary syndrome: a common but often unrecognized condition. J Midwifery Womens Health, 2012; 57 : $221-30$

Shukla S, Mehta A, Mehta P, Bajpai VK. Evaluation of comparative antidiabetic effects of ethanolic extracts of Caesalpinia bouncucella and Stevia rebaudianain normal and alloxan-induced experimental rats. Romanian Biotechnol Lett, 2011; 16:6187-99.

Shukla S, Mehta A, Mehta P, Vyas SP, Shukla S, Bajpai VK. Studies on anti-inflammatory, antipyretic and analgesic properties of Caesalpinia bonducella $\mathrm{F}$. seed oil in experimental animal models. Food Chem Toxicol, 2010; 48:61-4.

Spritzer PM. Polycystic ovary syndrome: reviewing diagnosis and management of metabolic disturbances. Arq Bras Endocrinol Metabol, 2014; 58(2):182-7.

Srivastava RK, Amitabh K. Pathophysiology of polycystic ovary syndrome (PCOS): lessons from animal studies. Proc India Natl Sci Acad, 2006; B71:191-205.

Teede H, Deeks A, Moran L. Polycystic ovary syndrome: a complex condition with psychological, reproductive and metabolic manifestations that impacts on health across the lifespan. BMC Med, 2010; $8: 41$

Teede H, Hutchison S, Zoungas S, Meyer C. Insulin resistance, the metabolic syndrome, diabetes and cardiovascular disease risk in women with PCOS. Endocrine, 2006; 30:45-53.

Wallace IR, McKinley MC, Bell PM, Hunter SJ. Sex hormone binding globulin and insulin resistance. Clin Endocrinol, 2013; 78(3) $321-9$.

White R. Legume web [Internet] version 10.01. Cardiff University, School of Computer Sciences, Cardiff, UK, c 2005 [Revised 2005 Nov 1]. Available via http://www.ildis.org/Legumeweb (Accessed 23 September 2008).

Yung Y, Maman E, Ophir L, Rubinstein N, Barzilay E, Yerushalmi GM, Hourvitz A. Progesterone antagonist, RU486, represses LHCGR expression and $\mathrm{LH} / \mathrm{hCG}$ signaling in cultured luteinized human mural granulosa cells. Gynecol Endocrinol, 2014; 30:42-7.

\section{How to cite this article:}

Meera Murugesan B, Muralidharan P, Hari R. Effect of ethanolic seed extract of Caesalpinia bonducella on hormones in mifepristone induced PCOS rats. J Appl Pharm Sci, 2020; 10(02):072-076 